Received Date : 25-Feb-2016

Revised Date :09-Jun-2016

Accepted Date : 01-Aug-2016

Article type : Systematic Review

\title{
Measurement properties of quality-of-life measurement instruments for infants, children and adolescents with eczema: a systematic review
}

\author{
D. Heinl ${ }^{1}$, C.A.C. Prinsen ${ }^{2}$, T. Sach ${ }^{3}$, A.M. Drucker ${ }^{4}$, R. Ofenloch ${ }^{5}$, C. Flohr $^{6}$, C. Apfelbacher ${ }^{1,7 \S}$ \\ 1 Medical Sociology, Institute of Epidemiology and Preventive Medicine, University of Regensburg, \\ Germany
}

2 VU University Medical Center, Department of Epidemiology and Biostatistics, EMGO+ Institute for Health and Care Research, Amsterdam, The Netherlands

3 Norwich Medical School, University of East Anglia, Norwich, United Kingdom

4 Department of Dermatology, The Warren Alpert Medical School of Brown University, Providence, $\mathrm{RI}, \mathrm{USA}$

5 Department of Clinical Social Medicine, University Hospital Heidelberg, Heidelberg, Germany

6 St John's Institute of Dermatology, Guy's \& St Thomas' NHS Foundation Trust and King's College London, London, United Kingdom

7 Division of Public Health and Primary Care, Brighton and Sussex Medical School, Falmer, United Kingdom

$\S$ corresponding author

Address details of corresponding author:

Christian Apfelbacher

Medical Sociology, Institute of Epidemiology and Preventive Medicine

University of Regensburg

Dr.-Gessler-Str. 17

93051 Regensburg

Germany

Tel.: +499419445231

Fax: +499419445252

E-Mail: christian.apfelbacher@klinik.uni-regensburg.de

This article has been accepted for publication and undergone full peer review but has not been through the copyediting, typesetting, pagination and proofreading process, which may lead to differences between this version and the Version of Record. Please cite this article as doi:

$10.1111 /$ bjd. 14966

This article is protected by copyright. All rights reserved. 
Running head: Eczema QoL measures for infants and young people: a systematic review

Conflicts of interest: All authors are ordinary members of the HOME initiative. Christian Apfelbacher is a member of the HOME Executive Committee. Carsten Flohr is a member of the Scientific Advisory Board of HOME. Aaron Drucker is involved with the development of a novel quality of life assessment instrument for atopic dermatitis that is as yet unpublished. The authors declare that they have no other competing interests.

Funding statement: The authors declare that they have not received any financial funding to conduct this study. Tracey Sach is funded by a Career Development Fellowship (CDF-2014-07-006) supported by the National Institute for Health Research. The views expressed in this publication are those of the author(s) and not necessarily those of the NHS, the National Institute for Health Research or the Department of Health. Carsten Flohr holds a UK National Institute for Health Research (NIHR) Career Development Fellowship (CDF-2014-07-037). The views expressed in this publication are those of the authors and not necessarily those of the NHS, the NIHR or the UK Department of Health.

\section{What's already known about this topic?}

- Most eczema trials include the Infants' Dermatitis Quality of Life Index (IDQoL) or the Children's Dermatology Life Quality Index (CDLQI) as quality of life (QoL) measurement instruments

- It is unclear which instruments are most appropriate to measure QoL in infants, children and adolescents with eczema

What does this study add?

- Most QoL instruments for infants, children and adolescents with eczema are poorly validated, indicating a clear need for further validation work

\section{Summary}

\section{Background}

Quality of life (QoL) is one of the core outcome domains identified by the Harmonising Outcome Measures for Eczema (HOME) initiative to be assessed in every eczema trial. There is uncertainty about the most appropriate QoL instrument to measure this domain in infants, children and adolescents.

\section{Objectives}

To systematically evaluate the measurement properties of existing measurement instruments developed and/or validated for the measurement of QoL in infants, children and adolescents with eczema.

\section{Methods}

A systematic literature search in PubMed and EMBASE, complemented by a thorough hand search of reference lists, retrieved studies on measurement properties of eczema QoL instruments for infants, children and adolescents. For all eligible studies, we judged the adequacy of the measurement properties and the methodological study quality with the COnsensus-based Standards for the selection of health Measurement INstruments (COSMIN) checklist. Results from different studies

This article is protected by copyright. All rights reserved. 
were summarized in a best evidence synthesis and formed the basis to assign four degrees of recommendation.

\section{Results}

17 articles, 3 of which were found by hand search, were included. These 17 articles reported on 24 instruments. No instrument can be recommended for use in all eczema trials because none fulfilled all required adequacy criteria. With adequate internal consistency, reliability and hypothesis testing, the US version of the Childhood Atopic Dermatitis Impact Scale (CADIS), a proxy-reported instrument, has the potential to be recommended depending on the results of further validation studies. All other instruments, including all self-reported ones, lacked significant validation data.

\section{Conclusions}

Currently, no QoL instrument for infants, children and adolescents with eczema can be highly recommended. Future validation research should primarily focus on the CADIS, but also attempt to broaden the evidence base for the validity of self-reported instruments.

\section{Systematic review registration: CRD42015023483}

Keywords: Core outcome set; eczema; HOME initiative; measurement properties; quality of life

\section{Introduction}

Affecting more than $10 \%$ of infants and children, eczema (synonyms: 'atopic eczema', 'atopic dermatitis') is one of the most common chronic diseases in children in many countries. ${ }^{1-3} \mathrm{~A}$ high eczema prevalence is also observed in adolescence, ${ }^{2}$ with a substantial risk of the disease persisting into adulthood. ${ }^{4}$ Despite a multitude of treatment options, evidence-based decision making based on systematic reviews and meta-analyses is hampered due to the heterogeneity of outcome measurement instruments used, particularly in randomized controlled trials.

Therefore, the Harmonising Outcome Measures for Eczema (HOME) initiative (www.homeforeczema.org) aims to develop a core outcome set (COS) for use in all future eczema trials. A COS is a minimum set of outcomes that should be measured and reported in all clinical trials of a specific disease or trial population. ${ }^{5}$ The core outcome domains suggested by the HOME initiative are clinical signs, symptoms, long-term control of flares and quality of life (QoL). ${ }^{6-8}$

Following the HOME roadmap, ${ }^{9}$ we performed a systematic review of the measurement properties of all instruments that were developed and validated to measure QoL in infants, children and adolescents with eczema. For adults, this step has already been completed. ${ }^{10}$

This article is protected by copyright. All rights reserved. 


\section{Material and Methods}

\section{Protocol and registration}

This systematic review was developed in accordance with the Preferred Reporting Items for Systematic Reviews and Meta-Analyses (PRISMA) statement. ${ }^{11}$ A completed PRISMA checklist is available as an online appendix to this publication. The study protocol was published ${ }^{12}$ and registered in the International Prospective Register of Systematic Reviews (PROSPERO): CRD42015023483.

\section{Literature search}

A systematic literature search in PubMed and EMBASE was conducted on 18 June 2015. The entire search strategy is shown in detail in the study protocol. ${ }^{12}$ Hand searching the PROQOLID database (http://www.proqolid.org) and reference lists of included studies and key articles on QoL in infants, children and adolescents with eczema complemented the systematic search.

\section{Eligible studies}

We applied the eligibility criteria presented in the protocol. ${ }^{12}$ Briefly, the study population of eligible development and validation studies of dermatology- or eczema-specific QoL instruments had to consist of at least $50 \%$ eczema patients younger than 16 years of age, or studies had to present subgroup analyses for this patient group.

\section{Content comparison}

The content of the included instruments was compared at the content domain level based on information from the original development paper.

\section{Assessment of the methodological quality of included studies}

We used the COnsensus-based Standards for the selection of health Measurement INstruments (COSMIN) checklist to judge the methodological quality of the included studies (www.cosmin.nl). ${ }^{13-16}$ This checklist consists of 5 to 18 items per measurement property covering methodological standards; the compliance with these standards is rated on a four-point rating scale (that is, 'poor,' 'fair,' 'good,' 'excellent'). The lowest rating for any item pertaining to a certain measurement property determines the overall rating for this measurement property.

\section{Assessment of measurement properties and further characteristics of QoL instruments}

With the exception of criterion validity, all measurement properties from the COSMIN checklist were evaluated in this systematic review. Where available, interpretability and feasibility data were collected. Because we view them as distinct instruments, different language versions of the same questionnaire were considered separately throughout this review except for content comparison and instrument characteristics.

\section{Assessment of the adequacy of the measurement properties}

To evaluate the adequacy of the investigated measurement properties, we applied the corresponding predefined criteria recommended by the COSMIN group in a slightly modified version (Table 1). ${ }^{17}$ The specific changes we made to these criteria are explained in the protocol. ${ }^{12}$ Where studies used item response theory (IRT) methods in the assessment of measurement properties instead of the development of measurement instruments, we assessed the adequacy and

This article is protected by copyright. All rights reserved. 
methodological quality of internal consistency, construct validity, structural validity, and crosscultural validity.

\section{Best evidence synthesis}

Findings on the same instrument from multiple studies were synthesized if the characteristics of the included studies were sufficiently similar, the results did not show considerably different or conflicting findings and the methodological quality of the included studies was adequate. ${ }^{18}$ Criteria for best evidence synthesis are found in Table 2.

\section{Generating recommendations for the use of QoL measurement instruments for eczema}

Depending on the adequacy of each instrument and the methodological quality of the included studies, a standardized recommendation for usage and necessary future validation work was made for each investigated instrument.

Four categories of recommendation were made: ${ }^{12}$

A. QoL measurement instrument meets all requirements and is recommended for use.

B. QoL measure meets two or more adequacy criteria, but performance in all other required adequacy criteria is unclear, so that the outcome measure has the potential to be recommended in the future depending on the results of further validation studies.

C. QoL measure has low adequacy in at least one required adequacy criterion ( $\geq 1$ rating of 'minus') and therefore is not recommended to be used any more.

D. QoL measure has (almost) not been validated. Its performance in all or most relevant adequacy criteria is unclear so that it is not recommended to be used until further validation studies clarify its adequacy.

Finally, we aimed to identify one best (currently available) instrument to assess QoL in infants, one best (currently available) instrument to assess QoL in children, and one best (currently available) instrument to assess QoL in adolescents with eczema.

\section{Results}

17 articles were included (Fig. 1). ${ }^{19-35}$ One paper complying with the inclusion criteria presented only summary information, making analyses of the evaluated questionnaires and measurement properties impossible; the paper was consequently excluded. ${ }^{36}$ Another paper containing data on the content validity of the Childhood Impact of Atopic Dermatitis (CIAD) did not formally meet inclusion criteria and was thus excluded. ${ }^{37}$ However, read in conjunction with the eligible development article of the $C I A D,{ }^{32}$ information on content validity could be extracted from that excluded paper and was therefore considered for this review.

Most included studies reported on the Children's Dermatology Life Quality Index (CDLQI, $n=6)^{20,27-}$ ${ }^{29,31,34}$ and the Infants' Dermatitis Quality of Life Index (IDQoL, $n=6$ ). ${ }^{19,22,23,27,30,35}$ Three studies evaluated the Childhood Atopic Dermatitis Impact Scale (CADIS) ${ }^{24,25,33}$ and two studies assessed the DISABKIDS Atopic Dermatitis Module (DISABKIDS-ADM). ${ }^{21,26}$ Information on the CIAD was available from two studies, ${ }^{32,37}$ but only one of them met the inclusion criteria. ${ }^{32}$

This article is protected by copyright. All rights reserved. 
A comparison of the content covered by these five instruments is presented in Table 3. The CDLQI and the IDQoL are the most similar in content out of the five instruments. Table 4 shows other general characteristics of the included instruments. The CADIS, CIAD and IDQoL are proxy-reported, whereas the CDLQI is completed by children themselves. The questionnaire DISABKIDS-ADM is available both in a self- and a proxy-reported version. Only the CDLQI is a dermatology-specific instrument, all others are eczema-specific. The lowest number of items in a questionnaire is 7 , the highest 45 . Four of the five questionnaires apply a 4- or 5-point Likert scale; only the CIAD uses a dichotomous response format.

\section{Characteristics of the included studies}

An overview of settings and study populations in the included studies is shown in Table 5. Most studies were conducted in secondary/tertiary care settings in Europe. Sample sizes ranged from 8 to 370 patients.

\section{Validity of the instruments and recommendations}

In total, we were able to rate the methodological quality of 84 measurement properties. Two measurement properties (2\%) had good, $18(21 \%)$ had fair and $64(76 \%)$ had poor methodological quality. Detailed results for every instrument and study investigated in this systematic review can be found in the online appendix to this article (Tables S1-S80).

\section{Proxy-reported instruments}

Table 6 shows the number of studies assessing the different measurement properties of each included proxy-reported QoL instrument. The results of best evidence synthesis and the degree of recommendation for each proxy-reported instrument are found in Table 7. There was no instrument for which all relevant measurement properties have been investigated. Hence, there was also no instrument that fulfilled all pre-specified requirements of truth, discrimination and feasibility.

With Cronbach's $\alpha$ ranging from 0.76 to 0.93 for its subscales, internal consistency of the US version of the CADIS was found adequate. ${ }^{24}$ Most language versions of the CIAD demonstrated also good internal consistency, with Cronbach's $\alpha$ values between 0.72 and 0.85 . $^{32}$ For the other instruments, internal consistency assessment was either done methodologically poorly or was not done at all. Measurement error was not investigated for any of the proxy-reported instruments included. Good reliability was shown for the US version of the CADIS, with Intraclass Correlation Coefficients (ICC) of 0.89-0.95 for the domain scores and 0.96 for the total score between the two administrations. ${ }^{25} \mathrm{An}$ ICC of 0.89 was found for the Dutch IDQoL, proving this instrument adequately reliable. ${ }^{35}$ While three language versions of the CIAD obtained an indeterminate rating for reliability, there was either no evidence or only evidence from methodologically poor studies for the other instruments.

Data on content validity could be extracted for the US version of the CADIS, the UK version of the IDQoL and all language versions of the CIAD. However, all content validity assessments were done methodologically poorly. No clear rating could be assigned for the IRT methods used to investigate structural validity of the US version of the CIAD. ${ }^{32}$ Hypothesis testing was the measurement property most frequently evaluated, with information available for 14 of the 16 proxy-reported instruments. The two Italian CADIS versions correlated well with other QoL instruments; for instance, Spearman's correlation coefficients of 0.74 with the IDQoL and 0.68 with the Dermatitis Family Impact were found for the long Italian CADIS. ${ }^{33}$ Discriminative validity of the US version of the CADIS was proven adequate since the instrument could differentiate patients according to severity as measured by

This article is protected by copyright. All rights reserved. 
SCORing Atopic Dermatitis (SCORAD) ${ }^{25}$ Convergent validity of the UK version of the IDQoL was assessed in a study of fair methodological quality, but resulted in an indeterminate adequacy rating as only correlations with unrelated constructs were determined. ${ }^{30}$ Evidence on hypothesis testing for the remaining questionnaires was available from methodologically poor studies only. ${ }^{19,22,26,27,32,35}$ Likewise, we could not draw a conclusion on cross-cultural validity, which was assessed for the long version of the Italian CADIS and four language versions of the CIAD, due to poor methodological study quality. ${ }^{32,33}$

Responsiveness in eczema patients was investigated for only three questionnaires, but these assessments were of poor methodological quality. ${ }^{23,25,30,32}$

Values for the minimal important change (MIC), the minimal important difference (MID) or validated banding systems are not available for the IDQoL. ${ }^{38}$ Evidence from several included validation studies suggests that the IDQoL does not exhibit floor and ceiling effects (i.e. $\geq 15 \%$ of patients having the lowest/highest possible score). ${ }^{22,27,30,35}$ We could not find information on the interpretability of the other proxy-reported questionnaires. Completion time of the CADIS amounted to approximately 6 minutes in one study. ${ }^{24}$

\section{Self-reported instruments}

Table 8 shows the number of studies assessing the different measurement properties of each included self-reported QoL instrument. The results of best evidence synthesis and the degree of recommendation for each self-reported instrument are found in Table 9. There was no instrument for which all relevant measurement properties have been investigated. Hence, there was also no instrument that fulfilled all pre-specified requirements of truth, discrimination and feasibility.

Internal consistency assessments were available for four included self-reported QoL instruments, but all were conducted methodologically poorly. Measurement error was not evaluated for any selfreported instrument included. Both the Malay and the Mexican Spanish CDLQI were assigned an indeterminate rating for reliability, whereas this measurement property was not investigated for any other included self-reported instrument.

Content validity was only investigated for the unknown language version of the DISABKIDS-ADM, but the methodological study quality was poor. ${ }^{21}$ Information on structural validity of the included selfreported instruments was not available. Data on hypothesis testing was available for all instruments except the unknown language version of the DISABKIDS-ADM. We found an intermediate rating for discriminative validity of the Swedish CDLQI because the instrument was able to differentiate patients according to age, but could not distinguish patients with eczema only from patients with eczema and another allergic comorbidity. ${ }^{27}$ The assessments of construct validity of all other questionnaires were of poor methodological quality. Cross-cultural validity was not assessed for any self-reported QoL instrument included.

An investigation of responsiveness was available for the Danish CDLQI only, but was done methodologically poorly. ${ }^{28}$

Little information on interpretability is available for the self-reported QoL instruments. No floor and ceiling effects were found for the CDLQI in an analysis of 50 Swedish children with eczema. ${ }^{27}$ Similarly, the CDLQI showed no floor and ceiling effects in the 47 children participating in its

This article is protected by copyright. All rights reserved. 
development study. ${ }^{29} \mathrm{~A}$ recent meta-analysis provides an overview of CDLQI scores in different conditions, enabling comparisons of eczema patients' scores with those of patients suffering from other diseases and helping to interpret patients' CDLQI scores. ${ }^{39}$ Values for the MIC/MID for the CDLQI in eczema patients, as well as interpretability data for the DISABKIDS-ADM, could not be found.

\section{Discussion}

This systematic review assessed the measurement properties of five different QoL instruments for use in infants, children and adolescents with eczema. None of these instruments complied with all pre-specified filter criteria of truth, discrimination and feasibility, clearly indicating that more validation work is required.

\section{Strength and limitations of this review}

Strengths of this systematic review include a registered and published protocol, the application of a validated, precise search filter ${ }^{40}$ and of predefined eligibility criteria, and the use of the COSMIN checklist ${ }^{13-16}$ to judge the methodological quality of included studies. Every step of the review process was carried out by at least two reviewers. Furthermore, one reviewer (DH) was involved in every step of the review to ensure consistency across the participating reviewers. Discrepancies were resolved by frequent discussions within the whole team.

A limitation of this review is the fact that only PubMed and EMBASE were searched. A thorough hand search of reference lists of included studies, important reviews and the PROQOLID database retrieved ten articles of interest not found in our initial systematic search, three of which were judged eligible and included. Another limitation may be that we could not consider responsiveness results of the CIAD obtained in the whole European sample because the paper provided no corresponding country-specific data. Also, information on discriminative validity of the CIAD could not be considered because the specific $p$ values were not presented by McKenna et al. ${ }^{32}$

\section{Discussion of the results in light of other research}

Of all instruments reviewed, only the US version of the CADIS ${ }^{24}$ reached category $B$, hence having the potential to be recommended in the future depending on the results of further validation studies. All other questionnaires were placed in category $D$; their future use cannot be endorsed until further validation data is available.

The CADIS, intended for use in eczema patients 0-6 years of age, is an internally consistent, reliable questionnaire with adequate construct validity. Its conceptual framework is based on a literature review and directed focus sessions with experts and parents. Compared to the other included instruments, the CADIS is unique in that it assesses both the QoL of the affected infant or child and the QoL of their parents. Although the instrument provides a total score, separate scores for the domains relating to the child's QoL can also be calculated. Results from both the infant- or childrelated domains and the parent-related domains were considered for this systematic review. The 45item questionnaire was quickly completed. A disadvantage of the CADIS is that only three validated language versions of the instrument are currently available, with a validation study of a Spanish version being prepared for publication. ${ }^{41}$ The validation article of the Japanese CADIS version, still in press and recently published online ${ }^{42}$ was not investigated in this systematic review because it had not yet been available when our systematic review was conducted. It will be taken into account in

This article is protected by copyright. All rights reserved. 
the first update to this systematic review. Measurement error and structural validity of the CADIS have not yet been investigated. Moreover, future studies of improved methodological quality should look at content validity, cross-cultural validity, responsiveness and interpretability of the CADIS.

The major finding of this systematic review is that nearly all existing QoL instruments for infants, children and adolescents with eczema are lacking significant validation data and were hence classified in category D. One reason for this is that $76 \%$ of the measurement properties were investigated in a methodologically poor manner, as compared to $25 \%$ in our preceding systematic review assessing the measurement properties of adult eczema QoL instruments. ${ }^{10}$ Part of this difference can be attributed to a stricter approach in judging whether hypotheses were formulated $a$ priori when assessing hypothesis testing and responsiveness (item 4 in COSMIN box F, item 8 in COSMIN box I) in this review compared to the afore-mentioned review of adult eczema QoL instruments. However, only 16 of the 32 COSMIN boxes of hypothesis testing and responsiveness rated as 'poor' in this systematic review would obtain a better COSMIN rating if a less strict approach concerning hypotheses formulation was applied, still leaving $57 \%$ methodologically poorly investigated measurement properties in total. This result suggests that the methodological study quality is indeed worse than in the previous review on adult eczema QoL instruments.

In addition to insufficient or methodologically poor validation of most instruments included, interpretability data is also lacking. A MID of 2.5 points on the CDLQI has been found in psoriasis patients, ${ }^{43}$ but corresponding data for eczema patients do not exist. Similarly, a banding system to help interpreting CDLQI scores has been developed, ${ }^{44}$ but the study did not meet our eligibility criteria because it reported on general dermatology patients in abstract form only. Interpretability in eczema patients is an important topic future validation studies should address.

Only two of the five included instruments are self-reported by the affected children. While proxyreported measures, including the CADIS, may be particularly useful in infants and younger children, they are not suitable for older children and adolescents. As both the CDLQI and the DISABKIDS-ADM were placed in category $D$, there is currently no self-reported $Q$ oL instrument for paediatric eczema that can be recommended for use. CDLQI and DISABKIDS-ADM are also intended for use in adolescents. However, it has been argued that factors influencing adolescents' QoL are fundamentally different from those observed in children and adults, leading to the development of the adolescent-specific Skindex-Teen. ${ }^{45}$ The development study of this questionnaire was not eligible for this review, though. Future validation studies of self-reported QoL instruments should therefore investigate whether they are suitable for adolescents with eczema as well, or if separate instruments for this age group are needed.

\section{Recommendations to researchers, clinicians and decision makers}

Currently only the CADIS has the potential to be recommended for use depending on the results of further validation studies. These validation studies should include all existing language versions of the CADIS and specifically examine measurement error, content validity, structural validity, crosscultural validity, responsiveness and interpretability. If these studies find favourable measurement properties of the CADIS, it should be translated and validated in more languages to increase international applicability. As the IDQoL is the QoL instrument most often used in eczema trials involving infants, ${ }^{46}$ it seems also advisable to undertake further validation work for this questionnaire. Additionally, future validation research should focus on self-reported QoL instruments for children and adolescents with eczema included in this review (CDLQI and DISABKIDS-ADM). For

This article is protected by copyright. All rights reserved. 
the time being, since none of the investigated QoL instruments can be highly recommended, we suggest using the proxy-reported CADIS for infants and younger children with eczema, until formal consensus is reached by the HOME initiative. For older children and adolescents with eczema, there is currently no valid, reliable and feasible self-reported instrument. Trials in this age group should include the QoL instrument that in their authors' opinion is best suited for children and adolescents with eczema. In older adolescents, the two QoL instruments for adults with eczema placed in category B in a previous systematic review, ${ }^{10}$ the Quality of Life Index for Atopic Dermatitis $\left(Q \circ L_{I A D}\right)^{47}$ and the Dermatology Life Quality Index (DLQI), ${ }^{48}$ may be applicable.

\section{Abbreviations}

CADIS, Childhood Atopic Dermatitis Impact Scale; CDLQI, Children's Dermatology Life Quality Index; CIAD, Childhood Impact of Atopic Dermatitis; COS, core outcome set; COSMIN, COnsensus-based Standards for the selection of health Measurement INstruments; DISABKIDS-ADM, DISABKIDS Atopic Dermatitis Module; DLQI, Dermatology Life Quality Index; HOME, Harmonising Outcome Measures for Eczema; ICC, Intraclass Correlation Coefficient; IDQoL, Infants' Dermatitis Quality of Life Index; $I R T$, item response theory; MIC, minimal important change; MID, minimal important difference; PRISMA, Preferred Reporting Items for Systematic Reviews and Meta-Analyses; QoL, quality of life; QoLIAD, Quality of Life Index for Atopic Dermatitis; SCORAD, SCORing Atopic Dermatitis; UK, United Kingdom; US, United States (of America);

\section{Acknowledgments}

We owe a great debt of gratitude to Rosemary Humphreys (Budleigh Salterton, United Kingdom) who commented on this manuscript and our research results from a patient's and a caregiver's view. We are very grateful to Joanne Chalmers (Nottingham, United Kingdom) and Helen Scott (Nottingham, United Kingdom) for assisting us in finding colleagues that could help with foreign language articles. We are indebted to Valeria Aoki (Sao Paulo, Brazil), Jonathan Batchelor (Nottingham, United Kingdom), levgen Kozin (Regensburg, Germany), Haibo Liu (Nanjing, China) and Luigi Naldi (Bergamo, Italy) for their help with foreign language articles.

\section{Authors' contributions}

DH conceptualized the research plan for the systematic review, screened search results, extracted data, assessed measurement properties, coordinated the work of the other reviewers, wrote the manuscript and reviewed it for important intellectual content. CP screened search results, assessed measurement properties, helped with methodological questions, wrote the manuscript and reviewed it for important intellectual content. TS performed the literature search, screened search results, extracted data, assessed measurement properties and reviewed the manuscript for important intellectual content. AD screened search results, extracted data, assessed measurement properties and reviewed the manuscript for important intellectual content. RO screened search results, assessed measurement properties and reviewed the manuscript for important intellectual content. $\mathrm{RH}$ contributed to the study design and reviewed the manuscript for important intellectual content. CF extracted data, assessed measurement properties and reviewed the manuscript for important intellectual content. CA conceptualized the research plan for the systematic review, screened search results, extracted data, assessed measurement properties, wrote the manuscript and reviewed it for important intellectual content.

This article is protected by copyright. All rights reserved. 


\section{Tables}

Table 4: Characteristics of the different instruments.

\begin{tabular}{|c|c|c|c|c|c|}
\hline Characteristic & CADIS & CDLQI & CIAD & $\begin{array}{c}\text { DISABKIDS- } \\
\text { ADM }\end{array}$ & IDQoL \\
\hline $\begin{array}{c}\text { Target } \\
\text { population }\end{array}$ & $\begin{array}{c}\text { Children with } \\
\text { eczema aged 0- } \\
6 \text { years (and } \\
\text { their parents) }\end{array}$ & $\begin{array}{l}\text { Children with } \\
\text { skin disease } \\
\text { aged } 4-16 \text { years }\end{array}$ & $\begin{array}{l}\text { Children with } \\
\text { eczema }\end{array}$ & $\begin{array}{l}\text { Children and } \\
\text { adolescents } \\
\text { with eczema }\end{array}$ & $\begin{array}{l}\text { Infants with } \\
\text { eczema aged } \\
\text { under } 4 \text { years }\end{array}$ \\
\hline $\begin{array}{c}\text { Mode of } \\
\text { administration }\end{array}$ & Proxy-reported $^{a}$ & Self-reported ${ }^{b}$ & Proxy-reported $^{a}$ & $\begin{array}{l}\text { Self- or proxy- } \\
\text { reported }^{b}\end{array}$ & Proxy-reported $^{a}$ \\
\hline $\begin{array}{c}\text { Number of } \\
\text { items }\end{array}$ & $45 / 41 / 33^{*}$ & 10 & $9 / 7+$ & 12 & 10 \\
\hline $\begin{array}{l}\text { Number of } \\
\text { subscales }\end{array}$ & 5 & 6 & ND & 2 & 8 \\
\hline $\begin{array}{l}\text { Number/type of } \\
\text { response } \\
\text { categories }\end{array}$ & $\begin{array}{l}\text { 5-point Likert } \\
\text { scale }\end{array}$ & $\begin{array}{l}\text { 4-point Likert } \\
\text { scale }\end{array}$ & $\begin{array}{l}\text { Dichotomous } \\
\text { (true/not true) }\end{array}$ & $\begin{array}{l}\text { 5-point Likert } \\
\text { scale (and 'not } \\
\text { applicable') }\end{array}$ & $\begin{array}{l}\text { 4-point Likert } \\
\text { scale }\end{array}$ \\
\hline $\begin{array}{l}\text { Scoring } \\
\text { algorithm }\end{array}$ & $\begin{array}{c}\text { Calculation of } \\
\text { domain scores } \\
\text { by summing up } \\
\text { item scores of } \\
\text { all items in one } \\
\text { domain; } \\
\text { calculation of a } \\
\text { total score by } \\
\text { summing up } \\
\text { scores of all } \\
\text { items in the } \\
\text { questionnaire }\end{array}$ & $\begin{array}{l}\text { Calculation of a } \\
\text { sum score, } \\
\text { range } 0-30\end{array}$ & ND & $\begin{array}{l}\text { Calculation of a } \\
\text { mean } \\
\text { standardized } \\
\text { score for each } \\
\text { dimension, } \\
\text { range } 0-100\end{array}$ & $\begin{array}{l}\text { Calculation of a } \\
\text { sum score, } \\
\text { range } 0-30\end{array}$ \\
\hline $\begin{array}{l}\text { Recall period in } \\
\text { the items }\end{array}$ & 4 weeks & 1 week & $\begin{array}{c}\text { None ('at the } \\
\text { moment') }\end{array}$ & ND & 1 week \\
\hline $\begin{array}{l}\text { Administration } \\
\text { costs }\end{array}$ & $\begin{array}{c}\text { No } \\
\text { administration } \\
\text { costs }^{41}\end{array}$ & $\begin{array}{l}\text { No charge for } \\
\text { non-funded } \\
\text { studies; } \$ 11.50 \\
\text { per patient for } \\
\text { pharmaceutical } \\
\text { companies }^{51}\end{array}$ & ND & ND & $\begin{array}{l}\text { No charge for } \\
\text { use in non- } \\
\text { funded studies } \\
\text { and routine } \\
\text { clinical practice; } \\
\$ 11.50 \text { per } \\
\text { patient for } \\
\text { pharmaceutical } \\
\text { companies }^{52}\end{array}$ \\
\hline $\begin{array}{c}\text { Available } \\
\text { translations }\end{array}$ & $\begin{array}{l}\text { English (US), } \\
\text { Italian, } \\
\text { Japanese }^{41}\end{array}$ & More than $50^{51}$ & $\begin{array}{c}\text { Dutch, English } \\
\text { (UK), English } \\
\text { (US), French, } \\
\text { German }\end{array}$ & $\begin{array}{c}\text { Brazilian } \\
\text { Portuguese, } \\
\text { other } \\
\text { languages } \$\end{array}$ & More than $20^{52}$ \\
\hline
\end{tabular}

a 'Proxy-reported' means that the (primary) caregiver of an infant fills in a questionnaire that assesses the quality of life of the infant. Proxy-reported instruments are often used in infants and younger children because they cannot report on their quality of life themselves due to their inability to read and a lack of understanding.

b 'Self-reported' instruments are used in older children and adolescents. These questionnaires are filled in by the children/adolescents themselves, not by their caregiver.

*45 items in the original version, 41 items in the long Italian version, 33 items in the short Italian version (Italian versions include fewer items as some were found to misfit in factor analysis).

t9 items in the Dutch, English (UK), French and German version each; 7 items in the English (US) version. The European versions and the US questionnaire have 6 items in common (of these, 3 are used as link items).

$\ddagger$ Not described which language versions were tested in the European validation study.

Abbreviations: CADIS, Childhood Atopic Dermatitis Impact Scale; CDLQI, Children's Dermatology Life Quality Index; CIAD, Childhood Impact of Atopic Dermatitis; DISABKIDS-ADM, DISABKIDS Atopic Dermatitis Module; IDQoL, Infants' Dermatitis Quality of Life Index; ND, not described; UK, United Kingdom; US, United States (of America).

This article is protected by copyright. All rights reserved. 
Table 5: Important characteristics of the included development and validation studies.

\begin{tabular}{|c|c|c|c|c|c|c|}
\hline & & \multicolumn{5}{|c|}{ Study characteristics } \\
\hline & & & & & \multicolumn{2}{|c|}{ Study population } \\
\hline $\begin{array}{l}\text { QoL } \\
\text { instrument }\end{array}$ & $\begin{array}{c}\text { Number } \\
\text { of } \\
\text { studies }\end{array}$ & $\begin{array}{l}\text { Geographic } \\
\text { location(s) }\end{array}$ & Language(s) & Setting(s) & $\begin{array}{c}\text { Number of } \\
\text { participants per } \\
\text { study }\end{array}$ & Age range \\
\hline $\begin{array}{c}\text { English } \\
\text { CADIS (US) }\end{array}$ & $2^{24,25}$ & $\begin{array}{l}\text { United } \\
\text { States of } \\
\text { America }\end{array}$ & English (US) & $\begin{array}{c}\text { Secondary/tertiary } \\
\text { care }\end{array}$ & 270 & $1.5-71.4 \mathrm{mos}$ \\
\hline $\begin{array}{c}\text { Italian } \\
\text { CADIS (long } \\
\text { version) }\end{array}$ & $1^{33}$ & Italy & Italian & $\begin{array}{c}\text { Secondary/tertiary } \\
\text { care }\end{array}$ & 135 & $2-72 \mathrm{mos}$ \\
\hline $\begin{array}{l}\text { Italian } \\
\text { CADIS } \\
\text { (short } \\
\text { version) }\end{array}$ & $1^{33}$ & Italy & Italian & $\begin{array}{c}\text { Secondary/tertiary } \\
\text { care }\end{array}$ & 135 & $2-72 \mathrm{mos}$ \\
\hline $\begin{array}{l}\text { Danish } \\
\text { CDLQI }\end{array}$ & $1^{28}$ & Denmark & Danish & $\begin{array}{c}\text { Secondary/tertiary } \\
\text { care }\end{array}$ & 35 & ND \\
\hline $\begin{array}{c}\text { English } \\
\text { CDLQI (UK) }\end{array}$ & $1^{29}$ & $\begin{array}{l}\text { United } \\
\text { Kingdom }\end{array}$ & English (UK) & $\begin{array}{c}\text { Secondary/tertiary } \\
\text { care }\end{array}$ & 47 & $\begin{array}{c}\text { ND } \\
\text { (mean } \pm S D: \\
9.2 \pm 3.6 \text { yrs) }\end{array}$ \\
\hline $\begin{array}{l}\text { Malay } \\
\text { CDLQI }\end{array}$ & $1^{20}$ & Malaysia & $\begin{array}{l}\text { Bahasa } \\
\text { Malaysia }\end{array}$ & $\begin{array}{c}\text { Secondary/tertiary } \\
\text { care }\end{array}$ & 33 & $\begin{array}{c}\text { ND } \\
\text { (youngest: } 7 \\
\text { yrs) }\end{array}$ \\
\hline $\begin{array}{l}\text { Serbian } \\
\text { CDLQI }\end{array}$ & $1^{31}$ & Serbia & Serbian & $\begin{array}{c}\text { Secondary/tertiary } \\
\text { care }\end{array}$ & 64 & $4-16$ yrs \\
\hline $\begin{array}{l}\text { Spanish } \\
\text { CDLQI } \\
\text { (Mexico) }\end{array}$ & $1^{34}$ & Mexico & $\begin{array}{l}\text { Mexican } \\
\text { Spanish }\end{array}$ & $\begin{array}{c}\text { Secondary/tertiary } \\
\text { care }\end{array}$ & 64 & $8-16$ yrs \\
\hline $\begin{array}{l}\text { Swedish } \\
\text { CDLQI }\end{array}$ & $1^{27}$ & Sweden & Swedish & $\begin{array}{c}\text { Secondary/tertiary } \\
\text { care }\end{array}$ & 50 & $5-15$ yrs \\
\hline \multirow{3}{*}{ Dutch CIAD } & \multirow{3}{*}{$1^{32,37} *$} & \multirow{3}{*}{ Netherlands } & \multirow{3}{*}{ Dutch } & \multirow{2}{*}{$\begin{array}{c}\text { Secondary/tertiary } \\
\text { care and } \\
\text { community }^{37}\end{array}$} & $\begin{array}{c}15 \text { (item } \\
\text { generation) }^{37}\end{array}$ & $N D^{37}$ \\
\hline & & & & & $\begin{array}{l}20 \text { (field } \\
\text { testing) }\end{array}$ & $N D^{37}$ \\
\hline & & & & Clinical trial $^{32} \dagger$ & $48^{32}$ & $\mathrm{ND}^{32}$ \\
\hline \multirow{3}{*}{$\begin{array}{l}\text { English } \\
\text { CIAD (UK) }\end{array}$} & \multirow{3}{*}{$1^{32,37 *}$} & \multirow{3}{*}{$\begin{array}{l}\text { United } \\
\text { Kingdom }\end{array}$} & \multirow{3}{*}{ English (UK) } & \multirow{2}{*}{$\begin{array}{c}\text { Secondary/tertiary } \\
\text { care and } \\
\text { community }^{37}\end{array}$} & $\begin{array}{c}35 \text { (item } \\
\text { generation) }^{37}\end{array}$ & $N D^{37}$ \\
\hline & & & & & $\begin{array}{l}20 \text { (field } \\
\text { testing) }\end{array}$ & $N D^{37}$ \\
\hline & & & & Clinical trial $^{32}+$ & $21^{32}$ & $\mathrm{ND}^{32}$ \\
\hline \multirow{2}{*}{$\begin{array}{l}\text { English } \\
\text { CIAD (US) }\end{array}$} & \multirow[b]{2}{*}{$1^{32,37 *}$} & \multirow{2}{*}{$\begin{array}{l}\text { United } \\
\text { States of } \\
\text { America }\end{array}$} & \multirow[b]{2}{*}{ English (US) } & $\begin{array}{c}\text { Secondary/tertiary } \\
\text { care and } \\
\text { community }^{37}\end{array}$ & $20^{37}$ & $N D^{37}$ \\
\hline & & & & Clinical trial ${ }^{32}+$ & $243^{32}$ & $\begin{array}{c}\text { ND } \\
\text { (mean } \pm S D: \\
48 \pm 21.6 \\
\text { mos) }\end{array}$ \\
\hline \multirow[t]{2}{*}{$\begin{array}{l}\text { French } \\
\text { CIAD }\end{array}$} & \multirow[t]{2}{*}{$1^{32,37 *}$} & \multirow[t]{2}{*}{ France } & \multirow[t]{2}{*}{ French } & $\begin{array}{c}\text { Secondary/tertiary } \\
\text { care and } \\
\text { community }^{37}\end{array}$ & $19^{37}$ & $N D^{37}$ \\
\hline & & & & Clinical trial $^{32}+$ & $52^{32}$ & $\mathrm{ND}^{32}$ \\
\hline \multirow[t]{2}{*}{$\begin{array}{l}\text { German } \\
\text { CIAD }\end{array}$} & \multirow[t]{2}{*}{$1^{32,37 *}$} & \multirow[t]{2}{*}{ Germany } & \multirow[t]{2}{*}{ German } & $\begin{array}{c}\text { Secondary/tertiary } \\
\text { care and } \\
\text { community }^{37}\end{array}$ & $19^{37}$ & $N D^{37}$ \\
\hline & & & & Clinical trial $^{32}+$ & $87^{32}$ & $\mathrm{ND}^{32}$ \\
\hline
\end{tabular}

This article is protected by copyright. All rights reserved. 


\begin{tabular}{|c|c|c|c|c|c|c|}
\hline \multirow{2}{*}{ Italian CIAD } & \multirow[t]{2}{*}{$1^{37 *}$} & \multirow[t]{2}{*}{ Italy } & \multirow{2}{*}{ Italian } & \multirow{2}{*}{$\begin{array}{c}\text { Secondary/tertiary } \\
\text { care and } \\
\text { community }\end{array}$} & $\begin{array}{c}15 \text { (item } \\
\text { generation) }\end{array}$ & ND \\
\hline & & & & & 8 (field testing) & ND \\
\hline $\begin{array}{l}\text { Spanish } \\
\text { CIAD }\end{array}$ & $1^{37} *$ & Spain & Spanish & $\begin{array}{c}\text { Secondary/tertiary } \\
\text { care and } \\
\text { community }\end{array}$ & 20 & ND \\
\hline $\begin{array}{l}\text { DISABKIDS- } \\
\text { ADM } \\
\text { (unknown } \\
\text { language) }\end{array}$ & $1^{21}$ & $\begin{array}{l}\text { ND }(2 \\
\text { European } \\
\text { countries) }\end{array}$ & ND & ND & 29 & ND \\
\hline $\begin{array}{c}\text { Portuguese } \\
\text { DISABKIDS- } \\
\text { ADM } \\
\text { (Brazil, } \\
\text { proxy- } \\
\text { reported } \\
\text { version) } \\
\end{array}$ & $1^{26}$ & Brazil & $\begin{array}{l}\text { Brazilian } \\
\text { Portuguese }\end{array}$ & $\begin{array}{c}\text { Secondary/tertiary } \\
\text { care }\end{array}$ & 52 & $8-18$ yrs \\
\hline $\begin{array}{c}\text { Portuguese } \\
\text { DISABKIDS- } \\
\text { ADM } \\
\text { (Brazil, self- } \\
\text { reported } \\
\text { version) } \\
\end{array}$ & $1^{26}$ & Brazil & $\begin{array}{l}\text { Brazilian } \\
\text { Portuguese }\end{array}$ & $\begin{array}{c}\text { Secondary/tertiary } \\
\text { care }\end{array}$ & 52 & $8-18$ yrs \\
\hline $\begin{array}{l}\text { Arabic } \\
\text { IDQoL }\end{array}$ & $1^{19}$ & Saudi Arabia & Arabic & $\begin{array}{c}\text { Secondary/tertiary } \\
\text { care }\end{array}$ & 370 & $\begin{array}{c}\mathrm{ND} \\
\text { (mean } \pm \mathrm{SD}: \\
8.8 \pm 9.9 \mathrm{mos}) \\
\end{array}$ \\
\hline $\begin{array}{l}\text { Dutch } \\
\text { IDQoL }\end{array}$ & $1^{35}$ & Netherlands & Dutch & Primary care & 66 & $0.5-83.5 \mathrm{mos}$ \\
\hline & & & & $\begin{array}{c}\text { Secondary/tertiary } \\
\text { care }^{23}\end{array}$ & $203^{23}$ & $1-53 \operatorname{mos}^{23}$ \\
\hline $\begin{array}{l}\text { English } \\
\text { IDQoL (UK) }\end{array}$ & $2^{23,30}$ & $\begin{array}{l}\text { United } \\
\text { Kingdom }\end{array}$ & English (UK) & $\begin{array}{l}\text { Secondary/tertiary } \\
\text { care and } \\
\text { community }\end{array}$ & 89 (validation) $^{30}$ & $\begin{array}{l}\text { ND (mean: } \\
20.16 \text { mos) }\end{array}$ \\
\hline & & & & $\begin{array}{c}\text { Secondary/tertiary } \\
\text { care }^{30}\end{array}$ & $\begin{array}{c}92 \\
\text { (development) }^{30}\end{array}$ & $N^{30}$ \\
\hline $\begin{array}{l}\text { Italian } \\
\text { IDQoL }\end{array}$ & $1^{22}$ & Italy & Italian & $\begin{array}{c}\text { Secondary/tertiary } \\
\text { care }\end{array}$ & 21 & $12-48 \mathrm{mos}$ \\
\hline $\begin{array}{l}\text { Swedish } \\
\text { IDQoL }\end{array}$ & $1^{27}$ & Sweden & Swedish & $\begin{array}{c}\text { Secondary/tertiary } \\
\text { care }\end{array}$ & 28 & $24-48$ mos \\
\hline
\end{tabular}

Abbreviations: CADIS, Childhood Atopic Dermatitis Impact Scale; CDLQI, Children's Dermatology Life Quality Index; CIAD, Childhood Impact of Atopic Dermatitis; DISABKIDS-ADM, DISABKIDS Atopic Dermatitis Module; IDQoL, Infants' Dermatitis Quality of Life Index; mos, months; $N D$, not described; QoL, quality of life; $S D$, standard deviation; UK, United Kingdom; US, United States (of America); yrs, years.

*The study by McKenna et al. from 2005 did not formally meet the inclusion criteria. However, read in conjunction with the eligible 2007 CIAD development article by McKenna et al., information on content validity of the CIAD could be extracted from the 2005 article. As a result, only the article by McKenna et al. from 2007 was formally included, but information from the 2005 article was also taken in consideration for content validity assessment.

These studies were conducted in the context of a clinical trial. No further information on the participating health service providers was presented, which is why it was not possible to group these study populations in one of the three categories community, primary care, or secondary/tertiary care.

This article is protected by copyright. All rights reserved. 
Table 7: Summary of measurement properties of proxy-reported QoL instruments for infants, children and adolescents with eczema.

\begin{tabular}{|c|c|c|c|c|c|c|c|c|c|c|c|c|c|c|c|c|}
\hline $\begin{array}{c}\text { Measure } \\
\text { ment } \\
\text { property }\end{array}$ & $\begin{array}{l}\text { Engl } \\
\text { ish } \\
\text { CAD } \\
\text { IS } \\
\text { (US) }\end{array}$ & $\begin{array}{c}\text { Itali } \\
\text { an } \\
\text { CAD } \\
\text { IS } \\
\text { (lon } \\
\text { g } \\
\text { versi } \\
\text { on) }\end{array}$ & $\begin{array}{c}\text { Itali } \\
\text { an } \\
\text { CAD } \\
\text { IS } \\
\text { (sho } \\
\text { rt } \\
\text { versi } \\
\text { on) }\end{array}$ & $\begin{array}{c}\text { Du } \\
\text { tch } \\
\text { CIA } \\
\text { D }\end{array}$ & $\begin{array}{c}\text { Engl } \\
\text { ish } \\
\text { CIA } \\
\text { D } \\
\text { (UK } \\
\text { ) }\end{array}$ & $\begin{array}{l}\text { Engli } \\
\text { sh } \\
\text { CIAD } \\
\text { (US) }\end{array}$ & $\begin{array}{c}\text { Fren } \\
\text { ch } \\
\text { CIAD }\end{array}$ & $\begin{array}{l}\text { Ger } \\
\text { man } \\
\text { CIAD }\end{array}$ & $\begin{array}{l}\text { Ital } \\
\text { ian } \\
\text { CIA } \\
\text { D }\end{array}$ & $\begin{array}{c}\text { Spa } \\
\text { nish } \\
\text { CIA } \\
\text { D }\end{array}$ & $\begin{array}{c}\text { Portug } \\
\text { uese } \\
\text { DISAB } \\
\text { KIDS- } \\
\text { ADM } \\
\text { (Brazil, } \\
\text { proxy- } \\
\text { report } \\
\text { ed } \\
\text { versio } \\
\text { n) }\end{array}$ & $\begin{array}{c}\text { Ara } \\
\text { bic } \\
\text { IDQ } \\
\text { ol }\end{array}$ & $\begin{array}{c}\text { Dut } \\
\text { ch } \\
\text { ID } \\
\text { Qo } \\
\text { L }\end{array}$ & $\begin{array}{l}\text { Engli } \\
\text { sh } \\
\text { IDQ } \\
\text { oL } \\
\text { (UK) }\end{array}$ & $\begin{array}{c}\text { Ital } \\
\text { ian } \\
\text { IDQ } \\
\text { oL }\end{array}$ & $\begin{array}{c}\text { Swe } \\
\text { dish } \\
\text { IDQ } \\
\text { oL }\end{array}$ \\
\hline $\begin{array}{c}\text { Internal } \\
\text { consistenc } \\
\mathrm{y}\end{array}$ & + & $\begin{array}{c}\text { Wea } \\
\text { k }\end{array}$ & $\begin{array}{c}\text { Wea } \\
\text { k }\end{array}$ & + & $\begin{array}{l}\text { We } \\
\text { ak }\end{array}$ & + & + & + & / & / & Weak & $\begin{array}{l}\text { We } \\
\text { ak }\end{array}$ & / & / & $\begin{array}{l}\text { We } \\
\text { ak }\end{array}$ & / \\
\hline $\begin{array}{c}\text { Measurem } \\
\text { ent error }\end{array}$ & / & / & / & / & / & / & / & / & / & / & / & / & / & / & / & / \\
\hline Reliability & + & $\begin{array}{c}\text { Wea } \\
\text { k }\end{array}$ & $\begin{array}{c}\text { Wea } \\
\text { k }\end{array}$ & $\begin{array}{l}\text { We } \\
\text { ak }\end{array}$ & $\begin{array}{l}\text { We } \\
\text { ak }\end{array}$ & $\begin{array}{c}? \\
\text { (limi } \\
\text { ted) }\end{array}$ & $\begin{array}{c}? \\
\text { (limi } \\
\text { ted) }\end{array}$ & $\begin{array}{c}? \\
\text { (limi } \\
\text { ted) }\end{array}$ & / & / & / & / & + & $\begin{array}{c}\text { Wea } \\
k\end{array}$ & $\begin{array}{c}\text { We } \\
\text { ak }\end{array}$ & / \\
\hline $\begin{array}{l}\text { Content } \\
\text { validity }\end{array}$ & $\begin{array}{l}\text { We } \\
\text { ak }\end{array}$ & / & / & $\begin{array}{c}\text { We } \\
\text { ak }\end{array}$ & $\begin{array}{l}\text { We } \\
\text { ak }\end{array}$ & $\begin{array}{c}\text { Wea } \\
k\end{array}$ & $\begin{array}{c}\text { Wea } \\
k\end{array}$ & $\begin{array}{c}\text { Wea } \\
k\end{array}$ & $\begin{array}{l}\text { We } \\
\text { ak }\end{array}$ & $\begin{array}{c}\text { Wea } \\
\mathrm{k}\end{array}$ & / & / & / & $\begin{array}{c}\text { Wea } \\
\mathrm{k}\end{array}$ & / & / \\
\hline $\begin{array}{l}\text { Structural } \\
\text { validity }\end{array}$ & / & $\begin{array}{c}\text { Wea } \\
\text { k }\end{array}$ & / & / & / & $\begin{array}{c}? \\
\text { (limi } \\
\text { ted) }\end{array}$ & / & / & / & / & / & / & / & / & / & / \\
\hline $\begin{array}{l}\text { Hypothesi } \\
\text { s testing }\end{array}$ & + & + & + & $\begin{array}{c}\text { We } \\
\text { ak }\end{array}$ & $\begin{array}{l}\text { We } \\
\text { ak }\end{array}$ & $\begin{array}{c}\text { Wea } \\
k\end{array}$ & $\begin{array}{c}\text { Wea } \\
k\end{array}$ & $\begin{array}{c}\text { Wea } \\
k\end{array}$ & / & / & Weak & $\begin{array}{c}\text { We } \\
\text { ak }\end{array}$ & $\begin{array}{l}\text { We } \\
\text { ak }\end{array}$ & $\begin{array}{c}? \\
\text { (limi } \\
\text { ted) }\end{array}$ & $\begin{array}{c}\text { We } \\
\text { ak }\end{array}$ & $\begin{array}{c}\text { Wea } \\
k\end{array}$ \\
\hline $\begin{array}{l}\text { Cross- } \\
\text { cultural } \\
\text { validity }\end{array}$ & / & $\begin{array}{c}\text { Wea } \\
\text { k }\end{array}$ & / & $\begin{array}{l}\text { We } \\
\text { ak }\end{array}$ & $\begin{array}{l}\text { We } \\
\text { ak }\end{array}$ & / & $\begin{array}{c}\text { Wea } \\
\text { k }\end{array}$ & $\begin{array}{c}\text { Wea } \\
k\end{array}$ & / & / & / & / & / & / & / & / \\
\hline $\begin{array}{c}\text { Responsiv } \\
\text { eness }\end{array}$ & $\begin{array}{l}\text { We } \\
\text { ak }\end{array}$ & / & / & / & / & $\begin{array}{c}\text { Wea } \\
k\end{array}$ & / & / & / & / & / & / & / & $\begin{array}{c}\text { Wea } \\
\mathrm{k}\end{array}$ & / & / \\
\hline $\begin{array}{c}\text { Recomme } \\
\text { ndation }\end{array}$ & B & D & D & D & D & D & D & D & D & D & D & D & D & D & D & D \\
\hline
\end{tabular}

Abbreviations: CADIS, Childhood Atopic Dermatitis Impact Scale; CIAD, Childhood Impact of Atopic Dermatitis; DISABKIDS-ADM, DISABKIDS Atopic Dermatitis Module; IDQoL, Infants' Dermatitis Quality of Life Index; QoL, quality of life; UK, United Kingdom; US, United States (of America).

Recommendations are defined as follows: $A$, QoL measurement instrument meets all requirements and is recommended for use; $B$, QoL measure meets two or more adequacy items, but performance in all other required adequacy items is unclear, so that the outcome measure has the potential to be recommended in the future depending on the results of further validation studies; $C$, QoL measure has low adequacy in at least one required adequacy criterion ( $\geq 1$ rating of 'minus') and therefore is not recommended to be used any more; $D$, QoL measure has (almost) not been validated. Its performance in all or most relevant adequacy items is unclear so that it is not recommended to be used until further validation studies clarify its adequacy.

+ , positive rating indicating adequate measurement property; ? (limited), intermediate rating indicating intermediate measurement property; Weak, measurement property was assessed only in studies of poor methodological quality (please refer to Table 2 for further details); / = not assessed.

This article is protected by copyright. All rights reserved. 
Table 9: Summary of measurement properties of self-reported QoL instruments for infants, children and adolescents with eczema.

\begin{tabular}{|c|c|c|c|c|c|c|c|c|}
\hline $\begin{array}{c}\text { Measurement } \\
\text { property }\end{array}$ & $\begin{array}{l}\text { Danish } \\
\text { CDLQI }\end{array}$ & $\begin{array}{c}\text { English } \\
\text { CDLQI } \\
\text { (UK) }\end{array}$ & $\begin{array}{l}\text { Malay } \\
\text { CDLQI }\end{array}$ & $\begin{array}{c}\text { Serbian } \\
\text { CDLQI }\end{array}$ & $\begin{array}{l}\text { Spanish } \\
\text { CDLQI } \\
\text { (Mexico) }\end{array}$ & $\begin{array}{l}\text { Swedish } \\
\text { CDLQI }\end{array}$ & $\begin{array}{c}\text { DISABKIDS- } \\
\text { ADM } \\
\text { (unknown } \\
\text { language) }\end{array}$ & $\begin{array}{c}\text { Portuguese } \\
\text { DISABKIDS-ADM } \\
\text { (Brazil, self- } \\
\text { reported version) }\end{array}$ \\
\hline Internal consistency & 1 & I & Weak & Weak & Weak & 1 & 1 & Weak \\
\hline Measurement error & / & / & / & / & / & / & / & / \\
\hline Reliability & / & / & ? (limited) & / & ? (limited) & / & / & / \\
\hline Content validity & / & / & / & / & / & / & Weak & / \\
\hline Structural validity & I & I & I & I & I & I & I & I \\
\hline Hypothesis testing & Weak & Weak & Weak & Weak & Weak & ? (limited) & 1 & Weak \\
\hline Cross-cultural validity & / & / & / & / & / & / & / & / \\
\hline Responsiveness & Weak & I & 1 & 1 & 1 & 1 & 1 & I \\
\hline Recommendation & D & $\mathbf{D}$ & $\mathbf{D}$ & D & D & $\mathbf{D}$ & D & D \\
\hline
\end{tabular}

Abbreviations: CDLQI, Children's Dermatology Life Quality Index; DISABKIDS-ADM, DISABKIDS Atopic Dermatitis Module; QoL, quality of life; UK, United Kingdom; US, United States (of America).

Recommendations are defined as follows: $A$, QoL measurement instrument meets all requirements and is recommended for use; $B$, QoL measure meets two or more adequacy items, but performance in all other required adequacy items is unclear, so that the outcome measure has the potential to be recommended in the future depending on the results of further validation studies; $C$, QoL measure has low adequacy in at least one required adequacy criterion ( $\geq 1$ rating of 'minus') and therefore is not recommended to be used any more; $D$, QoL measure has (almost) not been validated. Its performance in all or most relevant adequacy items is unclear so that it is not recommended to be used until further validation studies clarify its adequacy.

? (limited), intermediate rating indicating intermediate measurement property; $+/-$, conflicting findings; Weak, measurement property was assessed only in studies of poor methodological quality (please refer to Table 2 for further details); /= not assessed.

\section{References}

1. Apfelbacher CJ, Diepgen TL, Schmitt J. Determinants of eczema: population-based crosssectional study in Germany. Allergy 2011; 66: 206-13.

2. Henriksen L, Simonsen J, Haerskjold A et al. Incidence rates of atopic dermatitis, asthma, and allergic rhinoconjunctivitis in Danish and Swedish children. J Allergy Clin Immunol 2015; 136: 360-6 e2.

3. Silverberg JI, Simpson EL. Associations of childhood eczema severity: a US population-based study. Dermatitis 2014; 25: 107-14.

4. Mortz CG, Andersen KE, Dellgren C et al. Atopic dermatitis from adolescence to adulthood in the TOACS cohort: prevalence, persistence and comorbidities. Allergy 2015; 70: 836-45.

5. Clarke M. Standardising outcomes for clinical trials and systematic reviews. Trials 2007; 8: 39.

6. Schmitt J, Langan S, Stamm T et al. Core outcome domains for controlled trials and clinical recordkeeping in eczema: international multiperspective Delphi consensus process. J Invest Dermatol 2011; 131: 623-30.

7. Schmitt J, Spuls P, Boers $\mathrm{M}$ et al. Towards global consensus on outcome measures for atopic eczema research: results of the HOME II meeting. Allergy 2012; 67: 1111-7.

8. Schmitt J, Williams H, Group HD. Harmonising Outcome Measures for Eczema (HOME). Report from the First International Consensus Meeting (HOME 1), 24 July 2010, Munich, Germany. Br J Dermatol 2010; 163: 1166-8.

9. Schmitt J, Apfelbacher C, Spuls PI et al. The Harmonizing Outcome Measures for Eczema (HOME) roadmap: a methodological framework to develop core sets of outcome measurements in dermatology. J Invest Dermatol 2015; 135: 24-30.

10. Heinl D, Prinsen CA, Deckert S et al. Measurement properties of adult quality-of-life measurement instruments for eczema: a systematic review. Allergy 2016; 71: 358-70.

11. Moher D, Liberati A, Tetzlaff J et al. Preferred reporting items for systematic reviews and meta-analyses: the PRISMA statement. PLoS Med 2009; 6: e1000097.

12. Heinl D, Prinsen CA, Drucker AM et al. Measurement properties of quality of life measurement instruments for infants, children and adolescents with eczema: protocol for a systematic review. Syst Rev 2016; 5: 25.

This article is protected by copyright. All rights reserved. 
13. Mokkink LB, Terwee CB, Knol DL et al. The COSMIN checklist for evaluating the methodological quality of studies on measurement properties: a clarification of its content. BMC Med Res Methodol 2010; 10: 22.

14. Mokkink LB, Terwee CB, Patrick DL et al. The COSMIN study reached international consensus on taxonomy, terminology, and definitions of measurement properties for health-related patient-reported outcomes. J Clin Epidemiol 2010; 63: 737-45.

15. Mokkink LB, Terwee CB, Patrick DL et al. The COSMIN checklist for assessing the methodological quality of studies on measurement properties of health status measurement instruments: an international Delphi study. Qual Life Res 2010; 19: 539-49.

16. Terwee CB, Mokkink LB, Knol DL et al. Rating the methodological quality in systematic reviews of studies on measurement properties: a scoring system for the COSMIN checklist. Qual Life Res 2012; 21: 651-7.

17. Terwee CB, Bot SD, de Boer MR et al. Quality criteria were proposed for measurement properties of health status questionnaires. J Clin Epidemiol 2007; 60: 34-42.

18. Furlan AD, Pennick V, Bombardier C et al. 2009 updated method guidelines for systematic reviews in the Cochrane Back Review Group. Spine (Phila Pa 1976) 2009; 34: 1929-41.

19. Alzolibani AA. Cultural adaptation of the Arabic version of the Infants` Dermatitis Quality of Life Index. Saudi Med J 2013; 34: 518-24.

20. Aziah MS, Rosnah T, Mardziah A et al. Childhood atopic dermatitis: a measurement of quality of life and family impact. Med J Malaysia 2002; 57: 329-39.

21. Baars RM, Atherton $\mathrm{Cl}$, Koopman HM et al. The European DISABKIDS project: development of seven condition-specific modules to measure health related quality of life in children and adolescents. Health Qual Life Outcomes 2005; 3: 70.

22. Baranzoni N, Scalone L, Mantovani L et al. Validation of the Italian version of the Infants' Dermatitis Quality of Life and Family Dermatitis indexes. G Ital Dermatol Venereol 2007; 142: 423-32.

23. Beattie PE, Lewis-Jones MS. An audit of the impact of a consultation with a paediatric dermatology team on quality of life in infants with atopic eczema and their families: further validation of the Infants' Dermatitis Quality of Life Index and Dermatitis Family Impact score. Br J Dermatol 2006; 155: 1249-55.

24. Chamlin SL, Cella D, Frieden IJ et al. Development of the Childhood Atopic Dermatitis Impact Scale: initial validation of a quality-of-life measure for young children with atopic dermatitis and their families. J Invest Dermatol 2005; 125: 1106-11.

25. Chamlin SL, Lai JS, Cella D et al. Childhood Atopic Dermatitis Impact Scale: reliability, discriminative and concurrent validity, and responsiveness. Arch Dermatol 2007; 143: 768-72.

26. Deon KC, Santos DM, Bullinger M et al. Preliminary psycometric assessment of the Brazilian version of the DISABKIDS Atopic Dermatitis Module. Rev Saude Publica 2011; 45: 1072-8.

27. Ganemo A, Svensson A, Lindberg M et al. Quality of life in Swedish children with eczema. Acta Derm Venereol 2007; 87: 345-9.

28. Holm EA, Wulf HC, Stegmann $\mathrm{H}$ et al. Life quality assessment among patients with atopic eczema. Br J Dermatol 2006; 154: 719-25.

29. Lewis-Jones MS, Finlay AY. The Children's Dermatology Life Quality Index (CDLQI): initial validation and practical use. Br J Dermatol 1995; 132: 942-9.

30. Lewis-Jones MS, Finlay AY, Dykes PJ. The Infants' Dermatitis Quality of Life Index. Br J Dermatol 2001; 144: 104-10.

31. Maksimovic N, Jankovic S, Marinkovic J et al. Health-related quality of life in patients with atopic dermatitis. J Dermatol 2012; 39: 42-7.

32. McKenna SP, Doward LC, Meads DM et al. Quality of life in infants and children with atopic dermatitis: addressing issues of differential item functioning across countries in multinational clinical trials. Health Qual Life Outcomes 2007; 5: 45.

33. Neri E, Agostini F, Gremigni P et al. Italian validation of the Childhood Atopic Dermatitis Impact Scale: a contribution to its clinical application. J Invest Dermatol 2012; 132: 2534-43.

This article is protected by copyright. All rights reserved. 
34. Ramirez-Anaya M, Macias ME, Velazquez-Gonzalez E. Validation of a Mexican Spanish version of the Children's Dermatology Life Quality Index. Pediatr Dermatol 2010; 27: 143-7.

35. van Valburg RW, Willemsen MG, Dirven-Meijer PC et al. Quality of life measurement and its relationship to disease severity in children with atopic dermatitis in general practice. Acta Derm Venereol 2011; 91: 147-51.

36. Chernyshov PV. [Creation and cross-cultural adaptation of ukrainian versions of questionnaires for assessment of quality of life of children with atopic dermatitis and their families]. Lik Sprava 2008: 124-8.

37. McKenna SP, Whalley D, Dewar AL et al. International development of the Parents' Index of Quality of Life in Atopic Dermatitis (PIQoL-AD). Qual Life Res 2005; 14: 231-41.

38. Basra MK, Gada V, Ungaro $S$ et al. Infants' Dermatitis Quality of Life Index: a decade of experience of validation and clinical application. Br J Dermatol 2013; 169: 760-8.

39. Olsen JR, Gallacher J, Finlay AY et al. Quality of life impact of childhood skin conditions measured using the Children's Dermatology Life Quality Index (CDLQI): a meta-analysis. $\mathrm{Br} J$ Dermatol 2016; 174: 853-61.

40. Terwee CB, Jansma EP, Riphagen, II et al. Development of a methodological PubMed search filter for finding studies on measurement properties of measurement instruments. Qual Life Res 2009; 18: 1115-23.

41. Personal Communication: Administration costs and available validated language versions of CADIS. Inquiry about administration costs and available validated language versions of CADIS by e-mail. [12/12/2015]

42. Yamaguchi C, Futamura M, Chamlin SL et al. Development of a Japanese Culturally Modified Version of the Childhood Atopic Dermatitis Impact Scale (JCMV-CADIS). Allergol Int 2016.

43. Langley RG, Paller AS, Hebert AA et al. Patient-reported outcomes in pediatric patients with psoriasis undergoing etanercept treatment: 12 -week results from a phase III randomized controlled trial. J Am Acad Dermatol 2011; 64: 64-70.

44. Waters A, Sandhu D, Beattie PE et al. Severity stratification of Children's Dermatology Life Quality Index (CDLQI) scores. Br J Dermatol 2010; 163: 121.

45. Smidt AC, Lai JS, Cella D et al. Development and validation of Skindex-Teen, a quality-of-life instrument for adolescents with skin disease. Arch Dermatol 2010; 146: 865-9.

46. Heinl D, Chalmers J, Nankervis $\mathrm{H}$ et al. Eczema Trials: Quality of Life Instruments Used and Their Relation to Patient-reported Outcomes. A Systematic Review. Acta Derm Venereol 2016; 96: 596-601.

47. Whalley D, McKenna SP, Dewar AL et al. A new instrument for assessing quality of life in atopic dermatitis: international development of the Quality of Life Index for Atopic Dermatitis (QoLIAD). Br J Dermatol 2004; 150: 274-83.

48. Finlay AY, Khan GK. Dermatology Life Quality Index (DLQI)--a simple practical measure for routine clinical use. Clin Exp Dermatol 1994; 19: 210-6.

49. PROMIS Methodology. Patient Reported Outcomes Measurement Information System (PROMIS) Standards 2015. Available at: http://www.nihpromis.org/science/methodology (last accessed 14/07/2015)

50. Schellingerhout JM, Verhagen AP, Heymans MW et al. Measurement properties of diseasespecific questionnaires in patients with neck pain: a systematic review. Qual Life Res 2012; 21: 659-70.

51. Children's Dermatology Life Quality Index (CDLQI): Department of Dermatology, University of Cardiff. Available at: http://sites.cardiff.ac.uk/dermatology/quality-of-life/childrensdermatology-life-quality-index-cdlqi/ (last accessed 12/12/2015)

52. The Infants' Dermatitis Quality of Life Index (IDQoL): Department of Dermatology, University of Cardiff. Available at: http://sites.cardiff.ac.uk/dermatology/quality-of-life/the-infantsdermatitis-quality-of-life-index-idqol/ (last accessed 12/12/2015)

This article is protected by copyright. All rights reserved. 
Records identified through database searching (Medline via

Pubmed and Embase, Jun 18, 2015) ( $n=5367$ )
Additional records identified through other sources

$$
(n=10)
$$

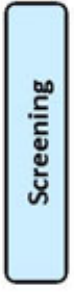

Records after duplicates removed

$$
(n=4744)
$$

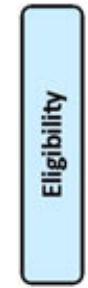

Full-text articles excluded, with reasons

$$
(n=48)
$$

tudies included in

qualitative synthesis ( $n=17)$

Studies included in quantitative synthesis (meta-analysis)

$$
(n=17)
$$
Analyses: The PRISMA Statement. PLoS Med 6(6): e1000097. doi:10.1371/journal.pmed1000097

For more information, visit www.prisma-statement.org.

This article is protected by copyright. All rights reserved. 